\title{
Short communication: Presence of neutral metallopeptidase (npr) gene and proteolytic activity of Bacillus cereus isolated from dairy products
}

\author{
M. T. M. Montanhini, ${ }^{*}$ M. Colombo, $†$ L. A. Nero, $\dagger^{1}$ and L. S. Bersot ${ }^{*} \ddagger^{1}$ \\ *Programa de Pós-Graduação em Engenharia de Alimentos, Universidade Federal do Paraná, Curitiba, PR, Brazil, 81531-980 \\ †Departamento de Veterinária, Universidade Federal de Viçosa, Viçosa, MG, Brazil, 36570-000 \\ łUniversidade Federal do Paraná, Campus Palotina, Palotina, PR, Brazil, 85950-000
}

\section{ABSTRACT}

The control of proteolytic microorganisms is one of the main challenges of the dairy industry, due to their spoilage activity that jeopardizes the quality of their products. Seventy-four Bacillus cereus strains isolated from powdered, UHT, and pasteurized milks were tested for the presence of the neutral metallopeptidase (npr) gene and proteolytic activity at 7, 10, 25, 30, and $37^{\circ} \mathrm{C}$. All strains had the npr gene, and proteolytic activity increased with the incubation temperature. The obtained results highlight the relevance of $B$. cereus as a spoiling agent in the dairy industry in terms of its genetic predisposition for proteolytic capacity, especially at room temperature.

Key words: Bacillus cereus, proteolysis, spoilage, psychrotrophic

\section{Short Communication}

Bacillus cereus is a psychrotrophic, spore-forming microorganism, usually associated with dairy spoilage due to its production of proteases and lipases (Senesi and Ghelardi, 2010). The presence of B. cereus in dairy products has been noted in several countries, indicating its relevance as a spoiling agent (Reyes et al., 2007; Rezende-Lago et al., 2007; Bartoszewicz et al., 2008; Zhou et al., 2008).

Proteases produced by the $B$. cereus strains are responsible for technological defects in dairy products, such as off-flavors, bitter taste, gel formation in UHT milk, and poor quality of cheeses (Chen et al., 2003; Vidal-Martins et al., 2005; Molva et al., 2009). Among the main proteases produced by $B$. cereus, the neutral metallopeptidases are highlighted; these enzymes are codified by the $n p r$ gene and are highly influenced by environmental factors such as temperature (Bach et al., 1999; von Stetten et al., 1999). The npr gene is a highly

Received April 2, 2013.

Accepted June 2, 2013.

${ }^{1}$ Corresponding authors: nero@ufv.br and lucianobersot@ufpr.br conserved gene of B. cereus, usually considered a reference for molecular detection of the proteolytic activity of this species (Bach et al., 2001). The present work aimed to identify the $n p r$ gene in $B$. cereus isolated from powdered, UHT, and pasteurized milks and evaluate protease production under controlled incubation temperatures.

In a previous study, 260 samples of powdered, UHT, and pasteurized milk were subjected to enumeration of B. cereus (Bennett and Belay, 2001) and 73 isolates were obtained and identified as belonging to this species (Montanhini et al., 2013). The isolates were stored in a tryptone soy broth (TSB; Oxoid Ltd., Basingstoke, UK) added to a $20 \%$ glycerol solution (vol/vol) at $-80^{\circ} \mathrm{C}$. At the moment of use, they were streaked onto tryptone soy agar plates (TSA; Oxoid Ltd.) and incubated at $30^{\circ} \mathrm{C}$ for $24 \mathrm{~h}$; the isolated colonies were transferred to a TSB and incubated at $30^{\circ} \mathrm{C}$ for $24 \mathrm{~h}$.

The DNA from the reactivated colonies was extracted and purified using a Wizard Genomic DNA Purification kit (Promega Corp., Madison, WI) and subjected to PCR to identify the npr gene, according to the protocol described by Bach et al. (2001), with the following modifications: $25-\mu \mathrm{L}$ PCR reactions comprised $12.5 \mu \mathrm{L}$ of GoTaq Green Master Mix (Promega Corp.), $1.0 \mu \mathrm{L}$ of the extracted DNA, $1.0 \mu \mathrm{L}$ of each primer (FP-npr: 5'-GTDGAYGCHCAYTAYTAYGC-3'; RP-npr: 5'-ACMGCATGBGTYADYTCATG-3', both at $100 \mathrm{pmol} /$ $\mu \mathrm{L}$ ), and $9.5 \mu \mathrm{L}$ of ultra-pure PCR water (Promega Corp.). The PCR conditions were as follows: initial denaturing at $95^{\circ} \mathrm{C}$ for $5 \mathrm{~min}, 30$ cycles at $95^{\circ} \mathrm{C}$ for 60 $\mathrm{s}$, annealing at $60^{\circ} \mathrm{C}$ for $30 \mathrm{~s}$, extension at $72^{\circ} \mathrm{C}$ for $60 \mathrm{~s}$, and final extension at $72^{\circ} \mathrm{C}$ for $60 \mathrm{~s}$. The PCR products were subjected to electrophoresis on $2.0 \%$ (wt/vol) agarose gels in a $0.5 \times$ Tris/borate/EDTA (TBE) buffer, stained with GelRed (Biotium Inc., Hayward, CA), and visualized in a transilluminator. Fragment sizes with 233 bp were related to the $n p r$ gene.

The obtained strains were also subjected to phenotypic trials to evaluate the production of proteases under different incubation temperatures, according to the methodology proposed by Marcy and Pruett 
Table 1. Frequency of positive results for the neutral metallopeptidase (npr) gene and proteolytic activity of 74 Bacillus cereus strains obtained from powdered, UHT, and pasteurized milk

\begin{tabular}{lccccccc}
\hline & & & \multicolumn{5}{c}{ Proteolysis at } \\
\cline { 5 - 8 } Origin & $\begin{array}{c}\text { No. of } \\
\text { samples }\end{array}$ & $\begin{array}{c}\text { Samples positive } \\
\text { for } n p r \text { gene (no.) }\end{array}$ & $7^{\circ} \mathrm{C}$ & $10^{\circ} \mathrm{C}$ & $25^{\circ} \mathrm{C}$ & $30^{\circ} \mathrm{C}$ & $37^{\circ} \mathrm{C}$ \\
\hline Powdered milk & 19 & 19 & 0 & 13 & 19 & 19 & 19 \\
UHT milk & 13 & 13 & 0 & 8 & 13 & 13 & 13 \\
Pasteurized milk & 42 & 42 & 0 & 34 & 42 & 42 & 42 \\
Total & 74 & 74 & 0 & 55 & 74 & 74 & 74 \\
\hline
\end{tabular}

(2001). Aliquots of $5 \mu \mathrm{L}$ of each colony were spotted in 5 replicates onto the surface of TSA plates and added to sterile skim milk at $10 \%$ (vol/vol). Plates were incubated at $7^{\circ} \mathrm{C}$ for $10 \mathrm{~d}, 10^{\circ} \mathrm{C}$ for $10 \mathrm{~d}, 25^{\circ} \mathrm{C}$ for $48 \mathrm{~h}$, $30^{\circ} \mathrm{C}$ for $48 \mathrm{~h}$, and $37^{\circ} \mathrm{C}$ for $48 \mathrm{~h}$. After incubation, the plates were flooded with $1 \% \mathrm{HCl}$ solution (vol/vol), with the excess poured off. Colonies with a transparent halo were recorded as positive for proteolytic activity.

Polymerase chain reaction results for the presence of the $n p r$ gene and the proteolytic activity of the strains are presented in Table 1. All strains presented the $n p r$ gene and proteolytic activity at temperatures equal to or higher than $25^{\circ} \mathrm{C}$, indicating their spoilage potential and protease expression at storage temperatures of UHT and powdered milks. At $10^{\circ} \mathrm{C}$, the expression of proteolytic activity decreased, being restricted to 55 isolates obtained mainly from pasteurized milk. However, at $7^{\circ} \mathrm{C}$, the proteolytic activity was completely inhibited. These results are similar to previous studies noting that the proteolytic activity of $B$. cereus increases when the incubation temperature increases (Molva et al., 2009; Samapundo et al., 2011).

Proteases produced by B. cereus are thermoresistant, representing a problem for processed dairy products even after the heat treatment of raw milk (Chen et al., 2003). In addition, B. cereus is a thermoduric microorganism; it can survive after heat treatments and is also capable of producing potential spoiling proteases in processed dairy products during the storage period (Bartoszewicz et al., 2008; Watanuki and Gallo, 2008). Because $B$. cereus is able to survive such heat treatments, its spoilage activity can decrease the quality of dairy products from the initial steps of production and throughout the retail sale storage. These observations are confirmed by the obtained data, as the storage temperatures of UHT and powdered milks allowed protease production, as did the marginal temperature of refrigeration of fresh fluid milk and dairy products (Table 1).

The low frequency of potential proteolytic strains at low temperatures (Table 1) should be evaluated carefully because $B$. cereus can produce proteases in these conditions without the expected activity (Kohlmann et al., 1991). The proteases could be produced at low temperatures, although they are only activated at higher temperatures $\left(25^{\circ} \mathrm{C}\right.$ or more; Chen et al., 2003). Because all strains had the $n p r$ gene, this proteolytic potential cannot be ignored, indicating its relevance to the spoilage of dairy products. Thus, the direct detection of the npr gene in milk and dairy products using molecular methods is an alternate way of estimating the spoilage potential of $B$. cereus in such products. The same methodology was proposed by Machado et al. (2013) for psychrotrophic microorganisms in raw milk, targeting several protease-related genes.

The obtained results indicate the spoilage potential of $B$. cereus strains isolated from powdered, UHT, and pasteurized milk due to the presence of the npr gene, related to the codification of neutral metallopeptidases and the production of active proteases at temperatures typically adopted during the storage of dairy products.

\section{ACKNOWLEDGMENTS}

The authors thank Coordenação de Aperfeiçoamento de Pessoal de Nível Superior (CAPES; Brasília, DF, Brazil), Conselho Nacional de Desenvolvimento Científico e Tecnológico (CNPq; Brasília, DF, Brazil), Fundação Araucária (Curitiba, PR, Brazil), and Fundação de Amparo à Pesquisa do Estado de Minas Gerais (FAPEMIG; Belo Horizonte, MG, Brazil).

\section{REFERENCES}

Bach, H.-J., D. Errampalli, K. T. Leung, H. Lee, A. Hartmann, J. T. Trevors, and J. C. Munch. 1999. Specific detection of the gene for the extracellular neutral protease of Bacillus cereus by PCR and blot hybridization. Appl. Environ. Microbiol. 65:3226-3228.

Bach, H.-J., A. Hartmann, M. Schloter, and J. C. Munch. 2001. PCR primers and functional probes for amplification and detection of bacterial genes for extracellular peptidases in single strains and in soil. J. Microbiol. Methods 44:173-182.

Bartoszewicz, M., B. M. Hansen, and I. Swiecicka. 2008. The members of the Bacillus cereus group are commonly present contaminants of fresh and heat-treated milk. Food Microbiol. 25:588-596.

Bennett, R. W., and N. Belay. 2001. Bacillus cereus. Pages 311-316 in Compendium of Methods for the Microbiological Examination of Foods. Vol. 1. 4th ed. F. P. Downes and K. Ito, ed. American Public Health Association, Washington, DC.

Chen, L., R. M. Daniel, and T. Coolbear. 2003. Detection and impact of protease and lipase activities in milk and milk powders. Int. Dairy J. 13:255-275. 
Kohlmann, K. L., S. S. Nielsen, L. R. Steenson, and M. R. Ladisch. 1991. Production of proteases by psychrotrophic microorganisms. J. Dairy Sci. 74:3275-3283.

Machado, S. G., D. M. Soares Bazzolli, and M. C. Dantas Vanetti 2013. Development of a PCR method for detecting proteolytic psychrotrophic bacteria in raw milk. Int. Dairy J. 29:8-14.

Marcy, J. A., and W. P. Pruett. 2001. Proteolytic microorganisms. Pages 183-185 in Compendium of Methods for the Microbiological Examination of Foods. Vol. 1. 4th ed. F. P. Downes and K. Ito, ed. American Public Health Association, Washington, DC.

Molva, C., M. Sudagidan, and B. Okuklu. 2009. Extracellular enzyme production and enterotoxigenic gene profiles of Bacillus cereus and Bacillus thuringiensis strains isolated from cheese in Turkey. Food Contr. 20:829-834.

Montanhini, M. T. M., M. T. M. Montanhini Neto, J. P. A. N. Pinto, and L. S. Bersot. 2013. Effect of temperature on the lipolytic and proteolytic activity of Bacillus cereus isolated from dairy products. Int. Food Res. J. 20:1421-1424.

Reyes, J. E., J. M. Bastías, M. R. Gutierrez, and M. de la O. Rodríguez. 2007. Prevalence of Bacillus cereus in dried milk products used by Chilean school feeding program. Food Microbiol. 24:1-6.

Rezende-Lago, N. C. M., O. D. Rossi Jr., A. M. C. Vidal-Martins, and L. A. Amaral. 2007. Occurrence of Bacillus cereus in whole milk and enterotoxigenic potential of the isolated strains. Arquivo Brasileiro de Medicina Veterinária e Zootecnia 59:1563-1569.

Samapundo, S., M. Heyndrickx, R. Xhaferi, and F. Devlieghere. 2011. Incidence, diversity and toxin gene characteristics of Bacillus cereus group strains isolated from food products marketed in Belgium. Int. J. Food Microbiol. 150:34-41.

Senesi, S., and E. Ghelardi. 2010. Production, secretion and biological activity of Bacillus cereus enterotoxins. Toxins (Basel) 2:16901703.

Vidal-Martins, A. M. C., O. D. Rossi, and N. C. Rezende-Lago. 2005. Mesophilic heterotrophic microorganisms and spore forming bacteria from Bacillus cereus group in ultra high temperature milk. Arquivo Brasileiro de Medicina Veterinária e Zootecnia 57:396-400.

von Stetten, F., R. Mayr, and S. Scherer. 1999. Climatic influence on mesophilic Bacillus cereus and psychrotolerant Bacillus weihenstephanensis populations in tropical, temperate and alpine soil. Environ. Microbiol. 1:503-515.

Watanuki, M. M., and C. R. Gallo. 2008. Detecção de Bacillus cereus em leite e avaliação da germinação dos esporos após tratamento térmico. Rev. Inst. Adolfo Lutz 67:202-207.

Zhou, G., H. Liu, J. He, Y. Yuan, and Z. Yuan. 2008. The occurrence of Bacillus cereus, B. thuringiensis and B. mycoides in Chinese pasteurized full fat milk. Int. J. Food Microbiol. 121:195-200. 